\title{
Szelenoészter-származékok daganatellenes és rezisztenciamódosító hatásának vizsgálata epidemiológiailag releváns daganatsejt-modellrendszerek felhasználásával
}

\author{
Gajdács Márió \\ Szegedi Tudományegyetem Általános Orvostudományi Kar, \\ Orvosi Mikrobiológiai és Immunbiológiai Intézet, Szeged
}

\begin{abstract}
Bevezetés: A szerves szelénvegyületekről számos kutatás bizonyítja, hogy képesek modulálni az emlőssejtek intracelluláris redox homeosztázisát, így hatékony és szelektív daganatellenes szerek lehetnek, mivel a daganatos sejtek érzékenyebbek a külső oxidatív stresszhatásokra. Célkitüzés: Újszerü szerkezettel rendelkező szerves szelénvegyületek daganatellenes és MDR-visszafordító hatásának vizsgálata különböző daganatsejtes modellrendszerek felhasználásával in vitro. Módszer: A vegyületek citotoxikus aktivitását MTT módszerrel határoztuk meg, az ABCB1 efflux transzporter gátlását rhodamin 123 akkumulációs vizsgálattal tanulmányoztuk áramlási citometriás módszerrel. A vegyületek apoptózist indukáló hatását Annexin V-FITC módszerrel határoztuk. OSIRIS Molecular Property Explorer és PreADMET 2.0 alkalmazásával becsültük meg a vegyületek fizikai-kémiai és in vivo abszorpciós tulajdonságait. Eredmények: Adott szerkezeti elemekkel (négy vegyület: egy ciklusos szelenoanhidrid és három alkil-keton-szelenoészter) rendelkező szelénvegyületek hatékonynak bizonyultak minden vizsgálatban, míg mások csökkent vagy semmilyen aktivitást nem mutattak; ezek a vegyületek erős citotoxikus hatásúak voltak a nanomoláris tartományban, emellett hatékonyan gátolták az ABCB1 efflux pumpát. A vegyületek lipofilitásának fontos szerepe van az effluxpumpa müködésének befolyásolásában. A ciklikus szelenoanhidrid hatékony korai apoptózist indukáló vegyület volt, míg az alkil-keton szelenoészterek nekrotikus folyamatokat indukáltak. Következtetések: Kísérleteink rávilágíttotak a szelén központi szerepére a rákellenes és az MDR-visszafordító hatás szempontjából. A vegyületek pontos molekuláris hatásmechanizmusa még nem ismert: azt feltételezhetjük, hogy a szelénvegyületek aktivitása a szelenoészter csoport hidrolíziséhez köthető. Eredményeink alapján az ígéretes vegyületek további származékainak szintézise és biológiai hatásának vizsgálata indokolt lehet.
\end{abstract}

Kulcsszavak: szelenoészter, szelenoanhidrid, multidrog-rezisztencia, ABCB1-transzporter, tumorsejtvonalak

\section{Evaluation of selenoester derivatives as antitumor and multidrug resistance-reversing agents on epidemiologically relevant cancer cell lines}

\begin{abstract}
Introduction: Numerous studies on organic selenium compounds have shown that they are capable of modulating intracellular redox homeostasis in mammalian cells, making them potent and selective anticancer agents, since tumor cells are more sensitive to external oxidative stress. Aim: Investigation of the antitumor and MDR reversibility effects of organically selenium compounds with novel structure using different tumor cell model systems in vitro. Method: The cytotoxic activity of the compounds was determined by MTT method. Inhibition of the ABCB1 efflux transporter was studied by flow cytometry using rhodamine 123 accumulation assays. The apoptosis inducing effect of the compounds was determined by the Annexin V-FITC method. The physicochemical and in vivo absorption properties of the compounds were predicted using OSIRIS Molecular Property Explorer and PreADMET 2.0. Results: Selenocompounds with particular structural elements (four compounds: one cyclic selenoanhydride and three alkyl-ketone selenocompounds) were effective in all assays, while others showed reduced or no activity; these compounds were cytotoxic in the nanomolar range and were effective in inhibiting the ABCB1 efflux pump. The lipophilicity of the compounds plays an
\end{abstract}

@ Levelezési cím: Dr. Gajdács Márió, Szegedi Tudományegyetem Általános Orvostudományi Kar, Orvosi Mikrobiológiai és Immunbiológiai Intézet, 6720 Szeged, Dóm tér 10., Tel.: +36-62-342-843, E-mail: mariopharma92@gmail.com 
important role in influencing the functioning of the efflux pump. Te cyclic selenoanhydride was a potent inducer of early apoptosis, while alkyl ketone selenate esters induced necrotic processes. Conclusions: Our experiments highlighted the central role of selenium in the anticancer and MDR reversing effects of these compounds. The exact molecular mechanism of action of the compounds is not yet known: it can be assumed that the activity of the selenium compounds can be linked to the hydrolysis of the selenoester group. Based on our results, synthesis of further derivatives and investigation of their biological activity may be warranted.

Keywords: selenoesters, selenoanhydrides, multidrug resistance, $\mathrm{ABCB} 1$ transporter, cancer cell lines

(Beérkezett: 2020. február 25.; elfogadva: 2020. június 15.)

\section{Rövidítések}

$\mathrm{ABC}=\mathrm{ATP}$-kötő kazetta; $\mathrm{ADME}=$ abszorpicó-disztribúció-metabolizmus-elimináció; ATP = adenozin-trifoszfát; Colo = vastagbél-adenokarcinóma; $\operatorname{cLog} P=$ oktanol/víz partíciós koefficiens tízes alapú logaritmusa; CYP = máj mikroszómális enzim; DMSO = dimetil-szulfoxid; ELISA = enzimkötött immunoszorbens assay; FAR = fluoreszcenciaaktivitási hányados; FITC = fluoreszcein-izotiocianát; HIA\% = humán intesztinális abszorpció; $\log S=$ vízoldékonyság tízes alapú logaritmusa; $M=$ molekulatömeg; MDR = multidrog-rezisztencia; $\mathrm{MTT}=$ 3-(4,5-Dimetil-2-tiazolil)-2,5-difenil-2H-tetrazólium bromid; $n$-OHNH = hidrogénkötés-donorok száma; $n$-ON = hidrogénkötés-akceptorok száma; PAR = szülői (érzékeny) sejtvonal; $\mathrm{PI}=$ propídium-jodid; PPB\% = plazmafehérje-kötődést; PS = foszfatidil-szerin; R123 = rhodamin 123; RO5 = Lipinsky-féle „ötös” szabály; ROS = reaktív oxigéngyök/oxigén intermedier; SDS = nátrium-dodecil-szulfát; SI = szelektivitási index; TPSA = molekulák topológiai poláris felülete

\section{Bevezetés}

A daganatos kórképek alatt számtalan, egymástól gyakran sok szempontból eltérő betegséget értünk, melyet az egészséges sejtek átalakulása jellemez szabályozatlanul osztódó és növekedő sejtekké, melyek veszélyeztetik az egészséges szövet és a szervezet valamennyi részének normális működését $[1,2]$. A daganatos megbetegedések a második vezető haláloknak számítanak, nemzetközi viszonylatban súlyos népegészségügyi problémát jelentenek. 2012-ben világszerte 8,2 millió daganatokhoz köthető halálesetet és 14,1 millió új rákos beteget regisztráltak, míg 32,6 millió ember lépett be az ötéves túlélés szakaszába [3, 4]. Az Európai Unió tagállamai közül Magyarország számolt be a legtöbb új esetről és a legmagasabb halálozási arányról a tüdőrák és a vastagbélrák tekintetében [5-8]. A daganatos megbetegedések számos etiológiai tényezőjét leírták: az egyén öröklött hajlama a betegségre, különböző életmódbeli szokások, környezeti faktorok és egyéb befolyásoló tényezők, mint az immunszupresszió és különböző gyógyszerek egyaránt daganatok kialakulásához vezethetnek [9].

A daganatterápia célja a rosszindulatú sejttömeg elpusztítása vagy méretének csökkentése, ezzel egy időben a beteg életminőségének javítása [10]. A rákos betegek terápiáját tekintve a sebészeti beavatkozások, a radioterápia és a kemoterápia (vagy magában vagy akár kombinál-

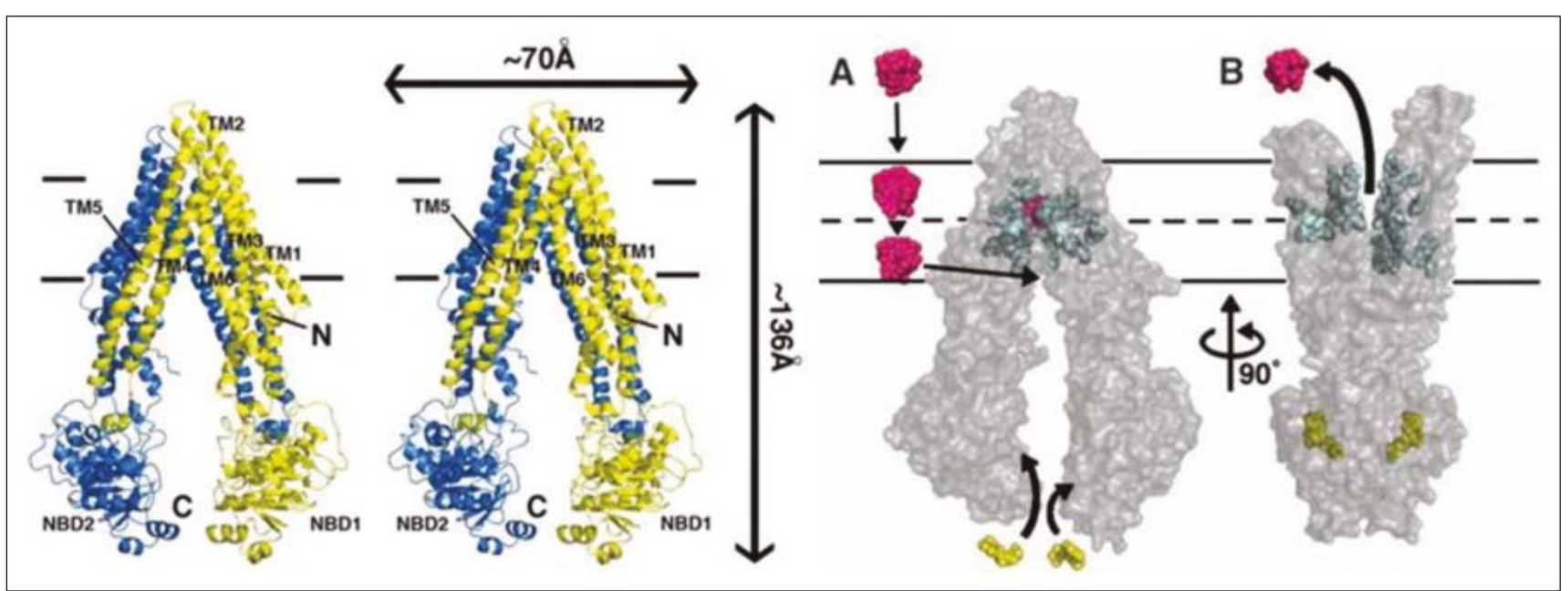

1. ábra. Az ABCB1 effluxtranszporter háromdimenziós szerkezete ([13] alapján) NBD: nukleotidkötő domén; TMD: transzmembrán domén; Å: angström; A: szubsztrát megkötése; B: szubsztrát kipumpálása 


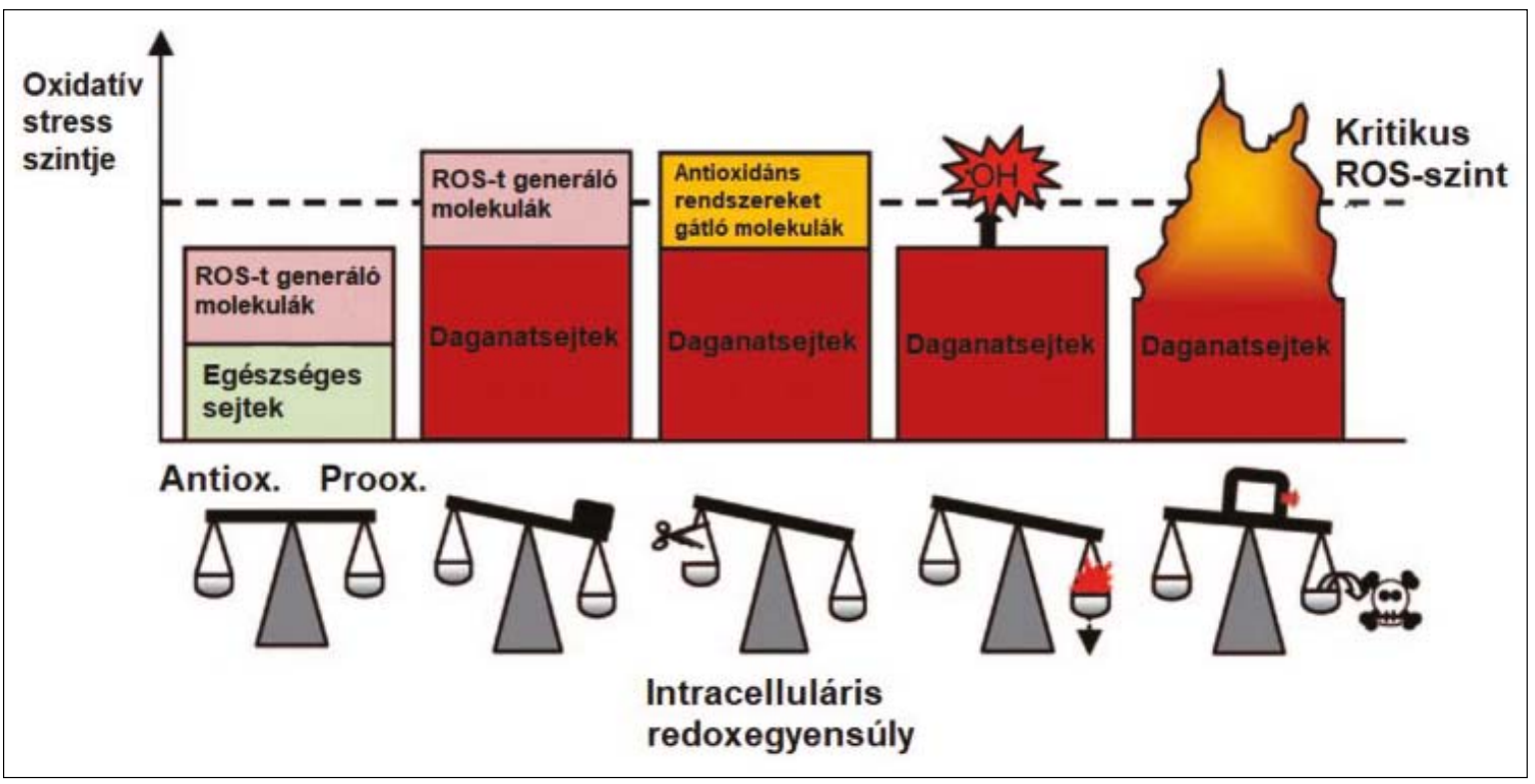

2. ábra. A redoxmoduláló vegyületek lehetséges hatásmechanizmusai daganatterápiában ([17] alapján). ROS: reaktív oxigén intermedierek, Antiox.: antioxidáns, Proox.: prooxidáns

va az előző kettővel) áll rendelkezésünkre [11]. A kemoterápia az egyik leggyakrabban használt kezelési mód a malignus hematológiai kórképek és a szolid tumorok tekintetében is. Azt a jelenséget, amikor a daganatsejtek több, egymástól kémiai szerkezetben és hatásmechanizmusban különböző kemoterápiás szerrel szemben mutatnak rezisztenciát, multidrog-rezisztenciának (MDR) nevezzük, melyet a tumorsejtek számos mechanizmuson keresztük képesek kialakítani [12]. Jelen kutatásunk során az energiafüggő effluxpumpák és az apoptózis gátlása által kialakult MDR kapott kitüntetett figyelmet. Az ATP-kötő kazetta (ABC; ATP-binding casette) transzportercsalád rendkívül jelentős és elterjedt csoportja a transzportfunkciót ellátó fehérjéknek az emberi szervezetben, melyek múködésük során az ATP hidrolíziséből felszabaduló energiát használják fel arra, hogy a fehérjét expresszáló sejtből eltávolítsanak különböző szubsztrátokat [13]. Az ABC transzporterek közül először az ABCB1 fehérjét írták le: a fehérje túltermelését gyakran hozták kapcsolatba hátrányos klinikai kimenetellel a daganatos betegség során. Ez a transzporter flexibilis szubsztrátkötő helyének köszönhetően többféle, egymással nem rokon szerkezetủ kemoterápiás szer kipumpálására képes (1. ábra) [13]. Feltörekvő kutatási irányvonalnak és terápiás stratégiának mutatkozik az effluxpumpagátlók alkalmazása, így javítani lehet a daganatellenes terápia hatékonyságát. A kemoterápiás szerek által kiváltott sejthalál egyik legjelentősebb formájának az apoptózist tekintik, az apoptotikus folyamatok károsodása vezethet MDR (terápia-refrakter) daganatokhoz [14].

Számos szervetlen és szerves szelénvegyületet vizsgáltak, mint kemopreventív és/vagy citotoxikus szert a daganatterápiában: ezeket az eredményeket nagy elemszámú epidemiológiai vizsgálat is alátámasztja $[15,16]$. A szelénvegyületek daganatellenes szerként való alkalmazásához füzött elképzelések azok redoxmoduláló hatásával függnek össze [16]. A szakirodalomban leírták, hogy a rákos sejtek sokkal érzékenyebbek az exogén oxidatív stresszre, mint az egészséges, nem tumoros sejtek. Ennek oka a reaktív oxigén intermedierek (ROS) fokozott szintje és az antioxidáns kapacitásuk maximális küszöbértéke, mivel a daganatsejtek csak intenzívebb metabolizmusukkal képesek fenntartani folyamatos sejtproliferációjukat (2. ábra) [17, 18]. A kísérletes vizsgálatok kezdetben a szervetlen szelénvegyületeket tanulmányozták citotoxikus hatásukra és kombinációs kemoterápiában való hatékonyságukra vonatkozóan, azonban későbbi eredmények rávilágítottak arra, hogy a szerves szelénvegyületek előnyösebb biológiai hatással rendelkeznek és kevésbé toxikusak [19]. Ezen vegyületeket számos in vitro daganatsejtes és állatkísérletes modellrendszerben vizsgálták, ahol ígéretes rákellenes és ROS-moduláló hatást mutattak önmagukban vagy klinikailag releváns kemoterápiás szerekkel kombinációban [20].

\section{Célkitűzések}

Vizsgálatunk célja Domínguez-Álvarez és mtsai által szintetizált, újszerű szerkezettel rendelkező szerves szelénvegyületek antitumor hatásának tanulmányozása különböző in vitro sejtvonalas modellrendszerek (egér és humán, tumoros és nem daganatos) felhasználásával. Citotoxikus hatásuk mellett a vegyületek multidrog-rezisztencia visszafordító hatását is vizsgáltuk két rezisztenciamechanizmusra (ABCB1 által mediált drog effluxgátlása és apoptózisindukció) vonatkozóan. Ezenfelül feltérképeztük fizikai-kémiai tulajdonságaikat, hogy további származékokat lehessen elóállítani, és in vivo is fel lehessen őket használni. 


\section{Módszerek}

\section{Vegyületek}

Kutatásunk során az alábbi vegyületeket vizsgáltuk: egy ciklikus szelenoanhidrid (1) és különböző funkciós csoportokkal rendelkező szelenoészterek (2-11; (2-5: metilcsoport; 6: amid; 7-8: karboxil-észter; 9-11: keton) (3. ábra). A vegyületek szintézisét és biológiai hatásuknak előzetes vizsgálatát Domínguez-Álvarez és mtsai írták le $[21,22]$. A vegyületeket DMSO-ban oldottuk fel a törzsoldatok (10 mM koncentrációban) elkészítéséhez. Ftálsav-anhidrid (12; az 1-es vegyület oxigén izosztere) és három szervetlen kalkogén-cianát (13-15; 13-KOCN, 14- $\left.\mathrm{NH}_{4} \mathrm{SCN}, 15-\mathrm{KSeCN}\right)$ referenciaként szerepelt kísérleteinkben [23]. Továbbá az alábbi vegyületek kerültek felhasználásra kísérleteink során: rhodamin 123 (R123; Sigma, St. Louis, MO, USA), 3-(4,5-dimethiltiazol-2-il)2,5-difeniltetrazólium-bromid (MTT; Sigma, St. Louis, MO, USA), nátrium-dodecil-szulfát (SDS; Sigma), verapamil (EGIS, Budapest, Magyarország), cisplatin (TEVA, Petah Tikva, Izrael) és dimetil-szulfoxid (DMSO; Sigma). Az apoptózis vizsgálathoz a pozitív kontroll M627 (12H-benzo[a]fenotiazin) kivételével minden reagenst az Annexin V-FITC Apoptosis Detection Kit (katalógusszám: PF 032, EMD Biosciences, Inc., La Jolla, CA) tartalmazott. A pozitív kontroll M627-et prof. dr. Noboru Motohashi bocsátotta rendelkezésünkre (Meiji Gyógyszerészeti Egyetem, Kiyose, Tokió, Japán), melyet DMSO-ban oldottunk fel. A rhodamin 123 törzsoldatát PBS-ben, a verapamil törzsoldatát vízben készítettük el.
Minden oldatot a vizsgálat napján, frissen készítettünk el.

\section{Sejtvonalak}

Az L5178Y egér T-sejtes limfóma sejtvonalat (PAR) (ECACC 87111908 katalógus számmal az amerikai Gyógyszer- és Élelmiszerellenőrző Hatóságtól került megvásárlásra) transzfektálták $\mathrm{pHa} \mathrm{MDR} 1 / \mathrm{A}$ retrovírussal, a Cornwell és mtsai. által leírt módszer alapján [24]. Az ABCB1-túltermelő sejtvonal (MDR) a transzfektált sejtek kolhicinnel való tenyésztésével került kiszelektálásra. A humán vastagbél-adenokarcinóma sejtvonal (Colo 205 doxorubicinérzékeny és Colo 320/MDR-LRP multidrogrezisztens, ABCB1-túltermelő (MDR1)-LRP), ATCCCCL-220.1 (Colo 320) és CCL-222 (Colo 205), az A549 humán tüdőadenokarcinóma sejtvonal (ATCC CCL-185), a NIH/3T3 egér embrionális fibroblaszt sejtvonal (ATCC CRL-1658) és az MRC-5 humán embrionális tüdőfibroblaszt (ATCC CCL-171) az LGC Promochemtől (Teddington, Egyesült Királyság) került megvásárlásra.

\section{Citotoxicitás vizsgálata}

A különböző szerkezetű szelénvegyületek sejtosztódásra gyakorolt hatását 96 lyukú mikrotiter lemezekben határoztuk meg. A harmadik oszlopba $196 \mu$ l tápfolyadékhoz $4 \mu \mathrm{l}$-t adtunk a szelenoészter származékok 10 mM-os koncentrációjú törzsoldataiból, innen hígítottuk tovább az anyagokat felező hígításos módszerrel, ezt követően mértük a megfelelő számú sejtet (1-1,5 $\times 10^{4} /$ lyuk) a mikrotiter lemez megfelelő oszlopaiba.

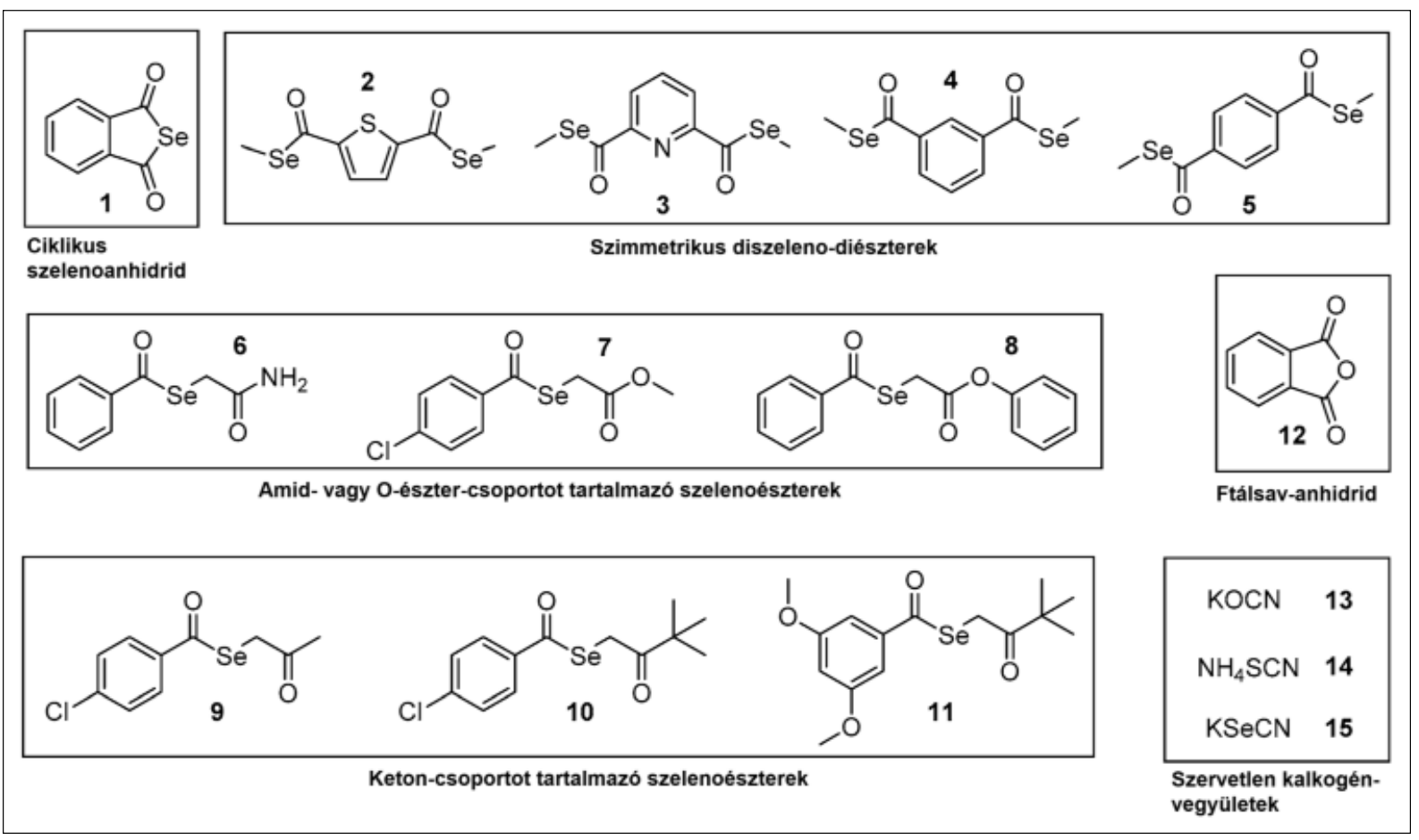

3. ábra. A vizsgált vegyületek szerkezeti képlete és szubsztituenseik szerinti felosztása 
A lemezeket $37^{\circ} \mathrm{C}$ hőmérsékleten inkubáltuk 24 órán át, $\mathrm{CO}_{2}$ termosztátban, az inkubáció után $20 \mu \mathrm{l}$ MTT-t ( $5 \mathrm{mg} / \mathrm{ml}$-es törzsoldatból, Sigma) mértünk a lemezekre, majd további 4 óra múlva $100 \mu \mathrm{l} 10 \%$ SDS (nátriumdodecil-szulfát)-HCl-elegyet mértük a mintákhoz, a formazán kristályok szolubilizálása végett, majd a lemezeket további 24 órán át inkubáltuk $\mathrm{CO}_{2}$ termosztátban $[22,23]$. A lemezek optikai denzitását (OD) Multiscan EX ELISA mikrotiter lemez-leolvasóval (Thermo Labsystem, Cheshire, Egyesült Államok) mértük 540 és 630 nm-en, hogy számszerü adatot kapjunk a sejtpusztulás mértékéről. A mérések során az $\mathrm{IC}_{50}$-értéket határoztuk meg, amely azt a koncentrációt jelenti, amelynél a vizsgált sejtek 50\%-a elpusztul a kontrollhoz képest, az alábbi képlet alapján:

$$
\mathrm{IC}_{50}=100-\left[\frac{\mathrm{OD} \text {-kezelt-OD-médiumkontroll }}{\text { OD-kezeletlen-OD-médiumkontroll }}\right] \times 100 \text {. }
$$

Szelektivitási indexeket (SI) számoltunk azért, hogy öszszehasonlítsuk a vizsgált vegyületek hatékonyságát a tumoros és nem daganatos sejtvonalon. A szelektivitási indexeket egy kvóciens formájában fejeztük ki, melyet úgy kaptunk, hogy a nem tumoros sejteken mért $\mathrm{IC}_{50}$-értékeket elosztottuk a daganatos sejtvonalakon (érzékeny, illetve MDR) kapott $\mathrm{IC}_{50}$-értékekkel. A vegyület erősen szelektívnek tekinthető, ha az SI értéke 6-nál nagyobb, mérsékelten szelektívnek, ha $3<\mathrm{SI}<6$, enyhén szelektívnek, ha $1<\mathrm{SI}<3$ és nem szelektívnek, ha SI kisebb mint 1 [23].

\section{Az ABCB1 effluxpumpagátlás vizsgálata}

A vizsgált vegyületek ABCB1 (P-glikoprotein) multidrog effluxpumpára gyakorolt gátló hatását rhodamin 123 (R123) akkumuláción alapuló, áramlási citometriás módszerrel vizsgáltunk az MDR egér T-sejtes limfóma és a rezisztens Colo320 humán vastagbél-adenokarcinóma sejtvonalon [25]. Verapamilt (EGIS, Budapest, Magyarország) használtunk pozitív kontrollként (20 $\mu \mathrm{M}$ koncentrációban), míg a DMSO oldószer kontrollként szerepelt (2 V/V\%) [23]. Valamennyi mintához 10-10 $\mu \mathrm{l}$ rhodamin 123 (R123, Sigma, St. Louis, MO, USA) festéket mérünk. A R123 egy nem toxikus, lipofil, kationos fluoreszcens festék $\left(\lambda_{e x / e m}=505 / 534 \mathrm{~nm}\right)$, amely az ABCB1-pumpa szubsztrátja. Mivel membránpermeábilis, az élő sejtek gyorsan felveszik, így MDR gátlószerekkel együtt az ABCB1-pumpa funkciójának mérésére használható [25]. A vizsgált sejtpopulációk fluoreszcenciáját Partec $\mathrm{CyFlow}^{\circledast}$ áramlási citométer (Partec, Münster, Germany) segítségével detektáltunk. Vizsgálatunk eredményeképpen fluoreszcencia aktivitási hányados (FAR) értékeket kaptunk, amelyek az alábbi összefüggés alapján határozhatóak meg, a kezelt és kezeletlen, érzékeny PAR és MDR sejtvonalak fluoreszcenciájának függvényében:

$$
\mathrm{FAR}=\frac{\mathrm{MDR}_{\text {kezelt }} / \mathrm{MDR}_{\text {kontroll }}}{\text { Érzékeny }_{\text {kezelt }} / \text { Érzékeny }_{\text {kontroll }}} .
$$

A vegyületek effluxpumpagátló hatását a verapamiléval hasonlítottuk össze, emellett egy FAR-kvóciens is kiszámításra került, az alábbi képlet alapján:

$$
\text { kvóciens }=100 \times\left(\mathrm{FAR}_{\text {vegyület }} / \mathrm{FAR}_{\text {verapamil }}\right) .
$$

\section{Az apoptózisindukció vizsgálata}

A szelénvegyületek apoptózist indukáló hatását az L5178Y egér T-sejtes limfóma (szülői és $A B C B 1$-transzfektált) és a rezisztens Colo 320 humán vastagbél-adenokarcinóma sejtvonalon vizsgáltuk in vitro. Az apoptózist az Annexin V-FITC apoptózisdetektáló kittel vizsgáltuk, a gyártó utasításai alapján [25]. Ez a módszer lehetővé teszi a korai és késői apoptotikus folyamatok és a sejthalál differenciálását, és kvantitatív eredményt ad a kezelt sejtpopulációról. Az apoptózis indukció vizsgálatánál annexin $\mathrm{V}$ foszfolipidkötő fehérjét használtunk a PS megkötésére, amelyhez fluoreszcein-izotiocianát (FITC) volt konjugálva mint fluoreszcens szubsztrát $\left(\lambda_{e x / \mathrm{em}}=\right.$ 495/519 nm), a fluoreszcens jelet áramlási citometriával detektáltuk. Mivel azoknál a sejteknél is megfigyelhető a PS-áthelyeződés, amelyek már nekrotikusak vagy elpusztultak, propídium-jodidos (PI) festést is $\left(\lambda_{e x / e m}=\right.$ 535/617 nm) alkalmazunk [26]. A két festés azért használható párhuzamosan, mert hullámhossz-tartományaikban nincsen átfedés. Pozitív kontrollként M627-et használtunk (12H-benzo[a]fenotiazin; $20 \mu \mathrm{M}$ ), amely egy benzotiazin származék és ismert korai apoptózist indukáló vegyület [27]. A DMSO oldószer kontrollként szerepelt ( $2 \mathrm{~V} / \mathrm{V} \%)$. A mérés elött a sejteket reszuszpendáltuk friss, szérummentes médiumban. Ezután elvégeztük az apoptózisvizsgálatot a kit „gyors” protokollja alapján, a vizsgált sejtpopulációk fluoreszcenciáját Partec CyFlow ${ }^{\circledast}$ áramlási citométer (Partec, Münster, Németország) segítségével detektáltunk.

\section{Prediktív in silico vizsgálat}

A vizsgált szelénvegyületek fizikai-kémiai és in vivo abszorpciós tulajdonságainak becslésére prediktív in silico vizsgálatot végeztünk OSIRIS Molecular Property Explorer (Actelion Pharmaceuticals, Allschwil, Svájc) és PreADMET 2.0 (Yonsei Egyetem, Seoul, Koreai Köztársaság), interneten ingyenesen elérhető szoftverek felhasználásával, hogy közelítő képet kaphassunk a szelénvegyületek, mint potenciális farmakon-jelöltek várható tulajdonságairól [28, 29]. A vizsgálat során a vegyületek alábbi tulajdonságait vizsgáltuk és értékeltük, hogy meghatározzuk a vegyületek illeszkedését a Lipinsky-féle ötös szabályhoz (RO5): molekulatömeg ( $M$ ), hidrogénkötés-donorok száma $(n$-OHNH), hidrogénkötés-akceptorok száma $(n-\mathrm{ON})$, oktanol/víz partíciós koefficiens tízes alapú logaritmusa $(\mathrm{c} \log P)$, vízoldékonyság tízes alapú logaritmusa $(\log S$; mol/l-ben kifejezve) és a molekulák topológiai poláris felülete (TPSA) [30]. Ezen felül, a szoftverek segítségével megbecsültük a vegyületek farmako- 
kinetikai tulajdonságait, így a plazmafehérje-kötődést (PPB\%), különböző monolayer modellrendszereken történő penetráció mértékét (Caco-2, MDCK), humán intesztinális abszorpció mértékét (HIA\%) és a különféle citokróm P450 enzimekkel való kölcsönhatást [30]. Az adatok összehasonlítása céljából különböző szerkezetű és hatásmechanizmusú, klinikailag releváns daganatellenes szereket (doxorubicin, gemcitabin, irinotekán, methotrexát, 5-fluorouracil) választottunk referenciaként. Meghatároztuk a vegyületek effluxpumpagátló hatásának (logFAR-értékben kifejezve) függését a becsült fizikaikémiai paraméterektől $(c \log P, \log S, \log$ TPSA, $M)$, korreláció-regresszió analízist végeztünk a Past 3.16 statisztikai program felhasználásával. Szignifikánsnak $p<$ 0,05 alatt tekintettük, emellett a determinációs együtthatót $\left(R^{2}\right)$ is számoltunk, amely a kölcsönhatás százalékos függését fejezi ki a változók között.

\section{Eredmények}

\section{Citotoxicitás vizsgálata}

A ciklikus szelenoanhidrid (1) és a 9-11-es számú szelenoészter erős citotoxikus hatással rendelkezett mind a szülői, mind az MDR egér T-limfóma sejteken ( $\mathrm{az} \mathrm{IC}_{50}$-érték az előbbire vonatkozóan 0,94-3,97 $\mu \mathrm{M}$, az utóbbira vonatkozóan 0,43-4,65 $\mu \mathrm{M}$ ), az utóbbi három vegyület daganatellenes hatását nanomólos tartományban is képes volt kifejteni, a legaktívabbnak bizonyuló szelenoészter (10) $\mathrm{IC}_{50}$-értéke $430 \mathrm{nM}$ volt MDR egér T-limfóma-sejteken. A 3-as és 6-os szelenoészterek szintén erős citotoxikus hatással rendelkeztek, azonban ezen aktivitásukat csak 5-40-szer magasabb koncentrációban voltak képesek kifejteni, mint az előző négy vegyület. A 9-11-es számú szelenoészter a nem daganatos egér embrionális fibroblasztsejteken is erősen toxikusnak bizonyult $(0,62-1,35$ $\mu \mathrm{M})$, míg a 2-es és 7-es $(23,72 \mu \mathrm{M})$, illetve a 6-os és 8-os $(69,69-74,47 \mu \mathrm{M})$ hasonló koncentrációkban volt toxikus. A 10-es vegyület mérsékelten volt szelektív (SI = 3,14), míg a szelenoanhidrid (1) kiváló szelektivitást mutatott $(\mathrm{SI} \geq 25,19)$ a daganatos sejtvonalak irányába. A humán vastagbél-adenokarcinóma sejteken végzett kísérletek alapján a 9-11-es számú szelenoészter erős citotoxikus hatással rendelkezett mind az érzékeny (Colo 205), mind a rezisztens (Colo 320) sejtvonalakon ( $\mathrm{az} \mathrm{IC}_{50}$-értékek 1,19-5,48 $\mu \mathrm{M}$ és $0,35-0,96 \mu \mathrm{M}$ ), a legaktívabb vegyület (9) $\mathrm{IC}_{50}$-értéke a Colo 320 sejteken $350 \mathrm{nM}$. Érdemes kiemelni, hogy a 9-es és 11-es szelenoészter mérsékelt-erős szelektivitást mutatott a Colo 320 (SI: $3,40-10,0)$ és a Colo 205 (SI: 4,2-14,40) sejtvonal irányába.

A ciklikus szelenoanhidrid (1) és két másik szelenoészter (4 és 8) hasonlóan ígéretesnek tekinthető, hisz nem voltak toxikusak a Colo 205 sejtvonalon, de aktívak voltak a rezisztens sejteken. A szelénvegyületekhez képest a pozitív kontollként használt ciszplatin $\mathrm{IC}_{50}$-értékei $11,36-$ 108,29-szor magasabbak voltak, mint a 9-11-es szelenoésztereké, emellett a szelénvegyületek 2,07-6,09-szer szelektívebbek voltak a vastagbél-adenokarcinóma sejteken. Ehhez hasonlóan, a 9-11-es szelenoészterek hatékony citotoxikus szereknek bizonyultak az A549 humán tüdő-adenokarcinóma sejtvonalon $\left(\mathrm{IC}_{50}: 5,91-15,22 \mu \mathrm{M}\right)$, két másik vegyülettel együtt (2 és 8), melyek $50 \mu \mathrm{M}$ körül bizonyultak hatásosnak. Azonban ezek a vegyületek csekély szelektivitást vagy annak teljes hiányát $(0,09-1,95)$ mutatták a tüdő-adenokarcinóma/tüdőfibroblaszt sejtvonalak vonatkozásában. A referencia vegyületek (12-15) nem rendelkeztek citotoxikus hatással egyik vizsgált sejtvonalon sem.

\section{$A z A B C B 1$ effluxpumpagátlás vizsgálata}

A tizenegy vegyület közül négy $(\mathbf{1}, \mathbf{9 - 1 1})$ rendelkezett jelentős ABCB1-gátló hatással (az R123 intracelluláris koncentrációja ezekben az esetekben volt a legnagyobb) MDR egér T-limfóma és Colo 320 humán vastagbél-adenokarcinóma sejteken, $20 \mu \mathrm{M}$-os koncentrációban. Az aktív vegyületek FAR kvóciensei a pozitív kontrollhoz (verapamil, $20 \mu \mathrm{M}$ ) képest 228,62-458,48\% között mozogtak. A két legaktívabb vegyület (a ciklikus szelenoanhidrid 1 és a 9-es szelenoészter) hatékonyabb ABCB1-gátló hatással rendelkezett a verapamilnál, még tízszer kisebb koncentrációban ( 20 vs. $2 \mu \mathrm{M}$ ) is, 202,58\%-as és $442,41 \%$ es FAR-kvóciens értékekkel. Hasonló eredményeket kaptunk az ABCB1-et túltermelő Colo 320 sejtvonalon: a ciklikus szelenoanhidrid 1 és a 9-11-es szelenoészter hatékony gátlószerei voltak az effluxprotein múködésének, túlszárnyalva a verapamil aktivitását $(\mathrm{FAR}=2,85) 2 \mu \mathrm{M}$-os koncentrációban (135,44-401,05\% közötti kvóciensértékekkel). A kutatás során vizsgált többi vegyület (2-8-as szelenoészterek és a 12-15-es referencia vegyületek) nem rendelkeztek a verapamilhoz mérhető effluxpumpagátló hatással egyik sejtvonalon sem.

\section{Az apoptózisindukció vizsgálata}

A vizsgált szelenoészterek hatásos apoptózist indukáló vegyületeknek bizonyultak az egér T-sejtes limfóma sejtvonalakon. A ciklikus szelenoanhidrid (1) és a 9-11 szelenoészter hatékonysága volt a legfigyelemreméltóbb a pozitív kontrollal összehasonlítva, ha az összes apoptotikus esemény számát vesszük alapul. A pozitív kontroll csak tízszer magasabb koncentrációban (2 vs. $20 \mu \mathrm{M})$ tudott az előbb említett vegyületekhez hasonló apoptózist indukáló hatást mutatni. Az MDR egér T-sejtes limfóma sejtvonalon elvégzett kísérletekben az 1-es vegyület kiemelkedő hatású volt, mert korai apoptózist indukált a vizsgált sejtpopuláció 32,2\%-ban (összesen 77,67\%-ban). Ezenfelül a 9-11-es szelenoészterek is aktívnak bizonyultak, azonban ezek biológiai hatását döntően késői apoptotózisként vagy nekrózisként detektáltuk. A vizsgált vegyületek hasonló mértékben indukáltak apoptózist a szülői egér T-sejtes limfóma sejtvonalon, azonban érdemes 
megjegyezni, hogy a 10-11-es szelenoészterek számottevően hatékonyabbak voltak az érzékeny sejtvonalon (apoptotikus események a vizsgált sejtpopuláció 39,01\% vs. $84,37 \%$-ban, illetve $47,16 \%$ vs. $92,46 \%$-ban). Az effluxpumpák szerepét az apoptózis indukció elkerülésében és a sejtmembrán stabilizálásában már leírták. Az effluxpumpák múködésének és a programozott sejthalál folyamatainak összefonódása lehetséges magyarázata a megfigyeléseinknek. Egy másik lehetséges magyarázat lehet az, hogy a vegyületek intracelluláris koncentrációja valószínüleg alacsonyabb az ABCB1 effluxpumpa müködésének következtében: míg mind a 9-11-es vegyület citotoxikus hatással rendelkezett $\mathrm{IC}_{50}<2 \mu \mathrm{M}$-s koncentrációban (a késői apoptózist/nekrózist okozó hatásukhoz az egér sejtekben), a 9-es szelenoészter hatékony effluxpumpagátló hatással rendelkezett $2 \mu \mathrm{M}$-os koncentrációban is, míg a 10-11-es vegyületek csak $20 \mu \mathrm{M}$-os koncentrációban mutatott hasonló aktivitást. Az eredményeink alapján a vegyületek hasonló mértékben okoztak késői apoptózist/nekrózist PAR sejteken, míg a 9-es vegyület kiugróan magas (2,8-3,9-szer magasabb) aktivitással bírt az MDR sejteken.

A vegyületek (1, 9-11) hasonló hatást mutattak a rezisztens humán vastagbél-adenokarcinóma (Colo 320) sejtvonalon (apoptózist indukáltak a vizsgált sejtpopuláció 64,6-80,5\%-ban). Összehasonlítva az eredményeket mind a három sejtvonalra vonatkozóan megfigyelhető, hogy a ciklikus szelenoanhidrid (1) hatékony korai apoptózist indukálónak bizonyult (32,2-66,1\%), míg a 9-11-es szelenoészter döntően késői apoptotikus/nekrotikus folyamatokat indított el, mely valószínüleg erős citotoxikus tulajdonságuknak köszönhető. Más szelénvegyületek (2-8) vagy a referencia vegyületek (12-15) nem rendelkeztek hasonló apoptózis indukáló hatással.

\section{Prediktiv in silico elemzés}

A szelénvegyületek fizikai-kémiai tulajdonságaikat tekintve összhangban vannak a releváns farmakológiai értékelési kritériumokkal és kivétel nélkül mindegyik megfelelt a Lipinsky-féle ötös szabálynak, szemben bizonyos referenciavegyületekkel (doxorubicin, methotrexát, irinotekán). A szerves szelénvegyületek várható kiváló orális biohasznosíthatósággal $(96,74-99,10 \%)$ rendelkeznek, és a Caco-2 egysejtrétegen becsült értékeik alapján mérsékelt permeabilitási tulajdonságokkal rendelkeznek. A prediktált plazmafehérje-kötődés (PPB\%) közel 100\%os az összes vizsgált szelénvegyület esetében, amely a szelénatom jelenlétének köszönhető a biológiailag aktív molekulákban. A vizsgált vegyületek előreláthatólag a CYP2C9 enzim inhibitorai és a 6-os vegyületet leszámítva a CYP3A4 enzim szubsztrátjai és inhibítorai, amely problémát jelenthet, ha ezeket a vegyületeket együtt adagolnák olyan daganatellenes szerekkel, amelyek ezeken az enzimeken metabolizálódnak. A vizsgált vegyületek effluxpumpagátló hatása (log FAR) és az oktanol/víz koefficiensük tízes alapú $\operatorname{logaritmusa~}(\operatorname{cog} P)$ között szig- nifikáns összefüggést találtunk mind az MDR egér T-sejtes limfómasejteken ( $\left.p=0,0034 ; R^{2}=0,6934\right)$, mind a Colo 320 humán vastagbél-adenokarcinóma sejteken $(p=$ 0,$\left.0198 ; R^{2}=0,5117\right)$. A vegyületek molekulatömege, a topológiai poláris felülete (TPSA), illetve a vízoldhatóságuk tízes alapú logaritmusa és a fluoreszcenciaadatok (log FAR) között nem találtunk jelentős összefüggést.

\section{Megbeszélés}

A fejlett országokban az öregedő népesség miatt a daganatos megbetegedések előfordulása előreláthatólag tovább fog növekedni [1-4]. A kemoterápia hatékony alkalmazását megnehezíti a szerek alacsony biohasznosíthatósága, alacsony szelektivitásukból adódó előnytelen mellékhatás profilja és a multidrog-rezisztencia kialakulása [31]. A multidrog-rezisztencia során a daganatsejtek több, különböző kémiai szerkezetű vagy hatásmechanizmusú szerrel szemben mutatnak rezisztenciát $[13,14]$. A jelen kutatómunka során az energiafüggő effluxpumpák által okozott rezisztencia és az apoptózis indukciógátlását vizsgáltuk. Számos olyan vegyületet írtak le, amely képes az ABCB1-transzporter funkcióját gátolni. Egy ígéretes terápiás stratégiának tartják különböző rezisztenciamódosító vegyületek alkalmazását adjuvánsként, hogy visszafordítsák a daganatos sejtek MDR fenotípusát [32]. Rengeteg szervetlen és szerves szelénvegyületet vizsgáltak daganatellenes hatásukra vonatkozóan. A szerves szelénvegyületek ismert modulátorai az emlőssejtek intracelluláris redox státuszának, ennél fogva hatékony és szelektív daganatellenes hatásúak lehetnek, mivel a daganatsejtek érzékenyebbek az exogén ROS-ra [17, 18]. A kutatás célja újszerü szerkezettel rendelkező szerves szelénvegyületek daganatellenes és MDR-visszafordító hatásának vizsgálata, a hazai daganatos betegségek epidemiológiai viszonyait figyelembe véve. Ezenfelül célkitűzéseink között szerepelt a szerkezet-hatás összefüggések meghatározása.

Eredményeink tükrében elmondható, hogy adott szerkezettel rendelkező vegyületek minden vizsgálat során figyelemre méltó aktivitással rendelkeztek, míg mások nem voltak hatékonyak egyik kísérletben sem. A referenciaként választott vegyületeknek (12-15) nem volt hatása egyik kísérletben sem. A citotoxicitási vizsgálatokban a szelénatom közvetlen közelében levő alkillánc természete meghatározó volt a daganatellenes hatás szempontjából. A ciklikus szelenoanhidriden (1) kívül a metil- (9) vagy terc-butilketon-szubsztitúció $(\mathbf{1 0}, \mathbf{1 1})$ volt a legelőnyösebb a citotoxikus hatás kifejeződéséhez. Az aromás gyưrưn található szubsztituensek hatása kevésbé volt jelentős a vegyületek daganatellenes hatása szempontjából. Általánosságban elmondható, hogy a szelénvegyületek az A549 humán tüdő-adenokarcinóma sejtvonalon voltak a legkevésbé aktívak és szelektívek. A 9-11-es szelenoészter kiemelkedő hatását az is igazolja, hogy $\mathrm{IC}_{50}$-értékeik több esetben is a nanomólos tar- 
tományban voltak és szelektivitási indexük is 6 felettinek bizonyult a humán vastagbél-adenokarcinóma sejteken. A ciklikus szelenoanhidrid (1) kiemelkedő szelektivitással rendelkezett egér sejtvonalakon (SI > 20) és nem mutatott toxicitást egyik nem tumoros sejtvonal iránt sem. A rhodamin 123 akkumulációs vizsgálatok eredményei összhangban vannak a citotoxicitási vizsgálatban megfigyeltekkel. A 4-klórfenil- szubsztituált metil-keton- szelenoészter (9) volt a legaktívabb vegyület ( $2 \mu \mathrm{M}$-os koncentrációban hatékonyabbnak bizonyult bármely más vegyületnél), melyet a ciklikus szelenoanhidrid (1) és a másik két metil-keton-szelenoészter $(\mathbf{1 0}, \mathbf{1 1})$ követ, melyek szintén hatékony ABCB1-gátlók voltak bírtak $20 \mu \mathrm{M}$-os koncentrációban. A 2-8-as szelenoészter effluxpumpa-moduláló hatása nem volt összehasonlítható a verapamillal. Fontos kiemelni, hogy a vegyületek lipofilicitása befolyásolta azok ABCB1moduláló hatását, mivel a cLog $P$-értékük szignifikáns összefüggést mutatott $(p<0,05)$ a számolt FAR-értékekkel. Az apoptózisvizsgálatban az előbb említett négy vegyület $(\mathbf{1}, \mathbf{9 - 1 1})$ az egér sejtvonalak esetén a sejtpopuláció 39,01-97,32\%-ban, a humán sejtvonalak esetén 64,60-71,40\%-ban volt képes kiváltani apoptózist. A ciklikus szelenoanhidrid (1) volt a leghatékonyabb korai apoptózist indukáló vegyület (az egér sejtvonal esetén a vizsgált sejtpopuláció egyharmadában, a vastagbél-adenokarcinóma sejtvonalak esetén a vizsgált sejtpopuláció kétharmadában), ezzel aktívabbnak bizonyult, mint a pozitív kontroll (M627). A metilketon-szelenoészterek ezzel szemben döntően nekrózist (az egér sejtvonalak esetén egészen $85,8 \%$-ig) okoztak. A két különböző típusú sejthalál megkülönböztetése fontos, hiszen a kemoterápia-indukált sejthalál szempontjából a korai apoptotikus folyamatok az előnyösek, hiszen nem szabadulnak fel gyulladásos mediátorok, amelyek károsítják a környező sejteket, szemben a nekrotikus folyamatokkal. A 2-8-as számú szelenoészter esetén az apoptózist indukáló hatás csekély volt vagy teljesen hiányzott. A humán vastagbél-adenokarcinóma sejtvonal érzékenyebbnek bizonyult a szelenoészterekkel történő kezelésre.

A kalkogén elemeket (S, Se, Te) tartalmazó szerves vegyületek iránt egyre nagyobb az érdeklődés a kísérletes kemoterápiás kutatásokban. A szakirodalom arra enged következtetni, hogy a csoport legaktívabb eleme a tellúr (Te), azonban ezek a vegyületek általában erős toxikus hatással és csekély szelektivitással rendelkeznek [33]. A szelénvegyületek előnye, hogy befolyásolják a különböző celluláris redox mechanizmusokat és szignál transzdukciós útvonalakat, ezért kifejezetten vonzóak a kutatók számára. A 12-es számú referenciavegyület, amely a ciklikus szelenoanhidrid oxigén-izosztere, nem mutatott értékelhető aktivitást egyik vizsgálat során sem, ami arra enged következtetni, hogy a Se-atom központi jelentőségü a vegyületek hatékonysága tekintetében. A vegyületek pontos molekuláris hatásmechaniz- musát még nem írták le. Előző vizsgálatok és Domínguez-Álvarez és mtsai hipotézise alapján a vegyületek biológiai hatása a szelenoészter csoport hidrolízisében keresendő. $\mathrm{Ez}$ a bomlás lehetővé teszi a szelénanionok felszabadulását a biológiai közegbe, így a töltéssel rendelkező szelénrészecskék bekapcsolódhatnak a legkülönfélébb oxido-redukciós folyamatokba [34]. Azt feltételezzük, hogy az új szelenoészterek „prodrug” formájában fejtik ki a hatásukat, így a molekulák képesek átjutni a sejtek citoplazmájába. A sejten belül a hordozómolekula bomlik, és felszabadítja az anionos karakterü részecskéket, amelyek citotoxikus hatással rendelkeznek. Az elektronszívó csoportok a molekulán belül (pl. keton, karboxilcsoport) elősegíthetik a lebomlás folyamatát, és stabilizálhatják a keletkező részecskéket. Azonban nem érdemes olyan származékokat tervezni, amelyeknek bomlása még a citoplazmán való átjutás elött bekövetkezik, hisz ebben az esetben az ionos karakterű részecskék már nem lesznek képesek átjutni a citoplazmán hidrofil karakterük miatt [34]. Bakteriális modellrendszerekben végzett kísérleteink rávilágítottak arra, hogy a vizsgált vegyületek biológiai hatásához oxigén jelenlétére van szükség, ami szintén erősíti a prodrug-hipotézist [35]. A ciklikus szelenoanhidrid (1) hatékonysága valószínüleg hasonlóan magyarázható, mint a 9-11-es vegyületek hatásmechanizmusa, bár a bomlás folyamatának és kinetikájának különbözőnek kell lennie, hisz ebben az esetben a Se-atom egy öttagú gyürürendszerben található. Ezenfelül nem világos még az sem, hogy a vizsgált vegyületek az ABCB1 kompetitív gátlószerei vagy a fehérje egy specifikus doménjéhez kötődnek. További kísérleteink során bizonyítottuk, hogy egyes Se-vegyületek ígéretesnek bizonyultak kombinációs kemoterápiában, kifejezetten a tioféngyürüt tartalmazó 2-es számú vegyület, amely szinergisztikus kölcsönhatást mutatott az összes vizsgált kemoterápiás szerrel (doxorubicin, ciszplatin, 5-fluorouracil, topotekán, ciklofoszfamid, vinkrisztin) [36].

Összegezve, négy vegyület került azonosításra mint kiváló vezérmolekula a további kísérletek tervezésére: a ciklikus szelenoanhidrid (1) és a 9-11-es számú szelenoészterek. Ezek a vegyületek kiváló daganatellenes és MDR-visszafordító (ABCB1-pumpamoduláló és apoptózisindukáló) hatással rendelkeztek. Figyelembe véve az in silico elemzés során kapott becsült eredményeket, a vegyületek előreláthatólag megfelelő in vivo biohasznosíthatósággal rendelkeznek és ígéretesek lehetnek a preklinikai és klinikai kutatási fázisba való átmenetben (lásd megfelelőségüket a RO5 szabálynak és a becsült abszorpciós értékeiket). A jövőbeli kutatásokat tekintve további szerkezeti variáns származékok tervezésére, szintézisére mindenképpen javasolt. Ezenfelül érdekes lehet a különböző szelénvegyületek vizsgálata kombinációs kemoterápiában különböző daganatellenes szerekkel in vitro, mert ez a kutatási terület is gazdag szakirodalommal rendelkezik. 


\section{Köszönetnyilvánítás}

A szerző köszönetét fejezi ki Dr. Spengler Gabriellának, az értékes tanácsokért és tudományos iránymutatásáért, továbbá a lehetőségért, hogy a kutatási területen tevékenykedhessen, illetve Vigyikánné Váradi Anikó laboratóriumi asszisztensnek a kiváló technikai segítségéért.

Nyilatkozat: Az alábbi kézirat a PhD-értekezésben történő megjelenésén kívül más folyóiratban korábban nem jelent meg és máshova beküldésre nem került. Nyilatkozom, hogy elolvastam a Hematológia-Transzfuziológia szerzői instrukcióit.

Érdekeltségek: A szerzőnek nincsenek érdekeltségei. Anyagi támogatás: A kutatás létrejöttét a Márton Áron Tehetséggondozó Program (2015/2016), a Márton Áron Kutatói Program (2016/2017 és 2017/2018) és az Új Nemzeti Kiválóság Program (ÚNKP-17-3) támogatta. A közlemény megírását a Szegedi Rákkutatásért Alapítvány (Prof. Dr. Molnár József) támogatta.

\section{Irodalom}

[1] World Health Organization. World Cancer Report. WHO, 2014 Available: http://www.who.int/cancer/publications/WRC_2014/ en/ [Accessed: February 2, 2020]

[2] Centers for Disease Control and Prevention. Cancer Data and Statistics. CDC, 2018. Available: https://www.cdc.gov/cancer/ dcpc/data/index.htm [Accessed: February 2, 2020]

[3] Jemal A, Bray F, Center MM, et al. Global cancer statistics. CA. Cancer J Clin. 2011; 61: 69-90.

[4] Siegel R, De Santis C, Virgo K, et al. Cancer treatment and survivorship statistics. CA Cancer J. Clin. 2013; 63: 11-30.

[5] Primic-Zakelj M, Zadnik V, Zagar T. Is cancer epidemiology different in Western Europe to that in Eastern Europe? J Eur Soc Med Oncol. 2005; 16: ii27-ii29.

[6] Központi Statisztikai Hivatal. A haláloki struktúra változása Magyarországon, 2000-2012. KSH, 2014. Available: https://www.ksh. hu/docs/hun/xftp/idoszaki/pdf/halalokistruk.pdf [Accessed: February 2, 2020]

[7] Molnár T, M. Barna K. Demographic characteristics in Hungary and the European Union, with special regard to cancer deaths [Demográfiai jellemzők Magyarországon és az Európai Unióban, különös tekintettel a daganatos megbetegedések okozta halálozásra]. Stat Szemle 2012; 90: 1-15 [Hungarian].

[8] Országos Onkológiai Intézet. Rákregiszter Statisztika. OOI, 2019. Available: http://www.onkol.hu/hu/rakregiszter-statisztika [Accessed: February 2, 2020]

[9] Loeb KR, Loeb LA. Significance of multiple mutations in cancer. Carcinogen. 2000; 21: 379-385.

[10] Chabner BA, Roberts TG. Chemotherapy and the war on cancer. Nat Rev Cancer 2005; 5: 65-72.

[11] Di Maio M, Gallo C, Leighl NB, et al. Symptomatic toxicities experienced during anticancer treatment: agreement between patient and physician reporting in three randomized trials. J Clin Oncol. 2015; 33: 910-915.

[12] Alfarouk KO, Stock CM, Taylor S, et al. Resistance to cancer chemotherapy: failure in drug response from ADME to P-gp. Cancer Cell Int. 2015; 15: 71.
[13] Housman G, Byler S, Heerboth S, et al. Drug resistance in cancer: an overview. Cancers 2014; 6, 1769-1792

[14] Amaral L, Spengler G, Molnár J. Identification of Important Compounds Isolated from Natural Sources that Have Activity Against Multidrug-resistant Cancer Cell Lines: Effects on Proliferation, Apoptotic Mechanism and the Efflux Pump Responsible for Multi-resistance Phenotype. Anticancer Res. 2016; 36: 5665-5672.

[15] Dodig S, Cepak I. The facts and controversies about selenium. Acta Pharm. 2004; 54, 261-276.

[16] Fernandes, AP, Gandin V. Selenium compounds as therapeutic agents in cancer. Biochim. Biophys. Acta 2015; 1850, 1642-1660.

[17] Estevam EC, Witek K, Faultich L, et al. Aspects of a Distinct Cytotoxicity of Selenium Salts and Organic Selenides in Living Cells with Possible Implications for Drug Design Molecules 2015; 20: 13894-13912.

[18] Jacob C. Redox signalling via the cellular thiolstat. Biochem Soc Trans. 2011; 39, 1247-1253.

[19] Jamier V, Ba LA, Jacob C. Selenium- and tellurium-containing multifunctional redox agents as biochemical redox modulators with selective cytotoxicity. Chem-Eur J 2010; 16, 10920-10928.

[20] Bartolini D, Sancineto L, Fabro de Bem A, et al. Selenocompounds in cancer therapy: An overview. Adv Cancer Res. 2017; 136, 259-302.

[21] Domínguez-Álvarez E, Plano D, Font M, et al. Synthesis and antiproliferative activity of novel selenoester derivatives. Eur J Med Chem. 2014; 73: 153-166.

[22] Domínguez-Álvarez E, Gajdács M, Spengler G, et al. Identification of selenocompounds with promising properties to reverse cancer multidrug resistance. Bioorg Med Chem Lett. 2016; 26: 2821-2824.

[23] Gajdács M, Spengler G, Sanmartín M, et al. Selenoesters and selenoanhydrides as novel multidrug resistance reversing agents: A confirmation study in a colon cancer MDR cell line. Bioorg Med Chem Lett. 2017; 27: 797-802.

[24] Cornwell MM, Pastan I, Gottesman MM. Certain calcium channel blockers bind specifically to multidrug-resistant human $\mathrm{KB}$ carcinoma membrane vesicles and inhibit drug binding to P-glycoprotein. J Biol Chem. 1987; 262: 2166-2170.

[25] Takács D, Csonka Á, Horváth Á, et al. Reversal of ABCB1-related multidrug resistance of colonic adenocarcinoma cells by phenothiazines. Anticancer Res. 2015; 35: 3245-3251.

[26] Logue SE, Elgendy M, Martin SJ. Expression, purification and use of recombinant annexin $\mathrm{V}$ for the detection of apoptotic cells. Nat Protoc. 2009; 4: 1383-1395.

[27] Mucsi I, Varga A, Kawase M, et al. Interaction between various resistance modifiers and apoptosis inducer $12 \mathrm{H}$-benzo[alpha] phenothiazine. Anticancer Res. 2002; 22: 2833-2836.

[28] Molecular Properties Prediction-Osiris Property Explorer. Available: https://www.organic-chemistry.org/prog/peo/ [Accessed: February 2, 2020].

[29] PreADMET: Prediction of ADME/Tox. Available: https://preadmet.bmdrc.kr/ [Accessed: February 2, 2020].

[30] Gajdács M, Handzlik J, Sanmartín C, et al. Prediction of ADME properties for selenocompounds with anticancer and efflux pump inhibitory activity using preliminary computational methods [Rákellenes és efflux pumpa gátló hatású szelénvegyületek ADME tulajdonságainak becslése számítógépes módszerrel] Acta Pharm Hung. 2018; 88: 67-74 [Hungarian].

[31] Stuurman FE, Nuijen B, Beijnen JH, et al. Oral anticancer drugs: mechanisms of low bioavailability and strategies for improvement. Clin Pharmacokiet 2013; 52: 399-414.

[32] Kunjachan S, Rychlik B, Storm G, et al. Multidrug resistance: Physiological principles and nanomedical solutions. Adv Drug Deliv Rev. 2013; 65: 1852-1865.

[33] Chen YC, Prabhu KS, Mastro AM. Is selenium a potential treatment for cancer metastasis? Nutrients 2013; 5: 1149-1168. 
[34] Álvarez-Pérez M, Ali W, Marć MA, et al. Selenides and diselenides: A review of their anticancer and chemopreventive activity. Molecules 2018; 23: 628.

[35] Spengler G, Kincses A, Mosolygó T, et al. Antiviral, antimicrobial and antibiofilm activity of selenoesters and selenoanhydrides. Molecules 2019; 23: 4264.
[36] Spengler G, Gajdács M, Marć MA, et al. Organoselenium compounds as novel adjuvants of chemotherapy drugs - A promising approach to fight cancer drug resistance. Molecules 2019; 24: 336.

A cikk a Creative Commons Attribution 4.0 International License (https://creativecommons.org/licenses/by/4.0/) feltételei szerint publikált Open Access közlemény, melynek szellemében a cikk bármilyen médiumban szabadon felhasználható, megosztható és újraközölhető, feltéve, hogy az eredeti szerző és a közlés helye, illetve a CC License linkje és az esetlegesen végrehajtott módosítások feltüntetésre kerülnek. (SID_1) 